Витебский государственный университет

имени П.М. Машерова

Филологический факультет

Кафедра иностранных языков

tel.: +375 212589673

e-mail: olsheverinova@yandex.ru

\title{
Прецедентное имя \\ в индивидуально-авторской картине мире \\ В. П. Астафьева
}

Ключевые слова: художественный текст, прецедентное имя, социокультурные сферы-источники, особенности функционирования, индивидуально-авторская картина мира.

Глобализация современного мира проецируется на научную парадигму, в рамках которой интегрируются исследования национальных и региональных компонентов в картине мира, одной из составляющей которой выступает художественная картина мира. В ней транслируется специфика творчества авторов, вербально реализуются историко-культурные и социальные процессы общества. Автор, выступающий субъектом воплощения информации, интерпретирует ее в соответствии со своими культурологическими и мировоззренческими интенциями, эстетическими взглядами, отношением к окружающей действительности. В силу этого реальная картина мира, пропущенная сквозь призму языковой личности автора и трансформированная с учетом его индивидуального замысла и стиля, становится как бы вторичной, индивидуально-авторской моделью существующей действительности.

Виктор Петрович Астафьев - известный российский писатель вт. пол. ХХ века, чье творчество, по мнению большинства критиков, 
реалистично и многопланово отражает особенности национального характера и мироведения русского народа.

Одним из ключевых компонентов понимания картины мира конкретного автора выступает антропонимическое пространство художественного текста, т.к. входящие в него единицы призваны обозначить и идентифицировать индивидуума по социальным, культурным и психологическим связям и сконструировать художественный образ, обладающий скрытыми ассоциациями и передающий национальный колорит. При этом прецедентное имя, являясь культурнозначимой единицей лингвокультурного сообщества и полноправным структурным элементом ономастикона произведений автора, репрезентирует, как отмечает Е.А. Нахимова, прецедентные концепты, которые используются для представления, категоризации, концептуализации и оценки действительности при построении картины мира и ее фрагментов [Нахимова 2007, 4].

Объектом настоящего исследования являются прецедентные имена как особая подсистема художественного ономастического пространства, репрезентирующая индивидуально-авторскую картину мира В.П. Астафьева.

В процессе анализа имен собственных, входящих в антропонимный фонд исследуемых произведений, нами выделено 147 прецедентных онимов. Для понимания роли прецедентного имени в авторской картине мире считаем целесообразным определить его социокультурные источники. Нами выделено 4 источника, представляющих разнообразные сферы социокультурного знания, к которым обращается в своих текстах В.П. Астафьев: «Искусство», «История», «Религия», «Наука».

Онимы, репрезентирующие сферу-источник «Искусство», составляют $53 \%$ от общего количества. Данная группа представлена именами:

1) реальных литературных деятелей (писателей, поэтов) и вымышленных литературных персонажей. Прецедентные антропонимы, входящие в первую подгруппу, соотносятся со следующими национальными литературами: русской - Александр Яшин, Алексей Прасолов, Баратьнский, Бунин, Василий Андреевич Жуковский, Герчен, Гоголь, Ершов, Куприн, Лермонтов и др.; французской - Бодлер, Эмиль Верхарн, Клод Фаррер, Сент-Экзюпери; немецкой - Гейне, Гете, Шиллер; итальянской - Данте, Кампанелла; казахской - Джамбул1;

1 Джамбул Джабаев, казахский народный поэт. 
балкарской - Кайсын Кулиев; исландской - Халлдор Лакснесс.

В состав второй подгруппы входят имена сказочных персонажей Аленушка, Василиса Прекрасная, Золушка, Иванушка, Иван-царевич, Кощей Бессмертньй, Лиса Патрикеевна, Пьеро, Хоттабыч, и литературных героев - Де Грие, Дездемона, Отелло, Дон Кихот, Санчо Пансо, Коленька Иртеньев, Печорин, граф Монте-Кристо, князь Переметьев, прини Датский, Дмитрий Николаевич/Рудин, Скотинин, Тарас Бульба, Фауст, Фаустус, а также имя героя художественного фильма - Мустафа ${ }^{2}$.

2) именами композиторов - Глюк, Григ, Калинников, Огинский, Сен-Санс, Шопен и др.; оперных/эстрадных певцов - Лемешев, Штоколов, Кобзон, Бобби Дилан;

3) киноактеров - Крючков, Ладынина, Нина Русланова, Серова, Смирнова;

4) жудожников - Шишкин, Рубенс, Суриков.

Самой многочисленной является первая группа. Широкая представленность в ней имен позволяет провести параллель между профессиональной деятельностью самого автора и его взглядами в этой области. Используемые имена реальных персон сферы прозаического и поэтического творчества, частота их употребления свидетельствуют не только об историко-культурном наследии словесного искусства, но и индивидуально авторских приоритетах и предпочтениях. Имена сказочных и литературных персонажей, героев фильма выступают в прозаической системе авторского произведения в качестве социокультурных знаков лингвокультур таких стран, как Россия, Франция, Англия, Испания, Германия. При этом отметим, что прецедентные имена, источником которых являются классические произведения художественной литературы, более востребованы автором и характеризуются большей воспроизводимостью.

Социокультурная сфера-источник «История» является второй по численности $(29 \%)$, но первой по частотности употребления группой в составе прецедентного антропонимикона произведений В.П. Астафьева. По семантической составляющей данных онимов выделяются следующие подгруппы:

1) руководители государств-Сталин, Брежнев, Гитлер, Наполеон, император Павел $\Omega^{3}$, иарь Лексей

2 Герой советского фильма Путевка в жизнь.

3 Император России (1796-1801) из династии Романовых.

4 Второй русский царь (1645-1676) из династии Романовых. 
2) государственные и политические деятели - Бенеш, Чемберлен, Берия, Ворошилов, Геббельс, Геринг, Дзержинский, Калин, Клара Цеткин, Ленин и др.;

3) военачальники, полководцы, флотоводцы - Ватутин, Гуртьев, Кирпонос, Паулюс, Георгий Константинович ЖУков, Кутузов, де Бель Иль, Нахимов, Суворов, Богдан Хмельничкий и др.;

4) представители народных движений - Ванщетти, Сакко, Пугачев, Стенька Разин, Тельман, Щетинкин ${ }^{5}$.

Антропонимы анализируемой сферы отсылают читателя в реально существующий внешний мир и соотносят изображаемые в произведениях события с историческими периодами, которые связаны непосредственно с обострением политической ситуации на международной арене. Соотношение онимов этой группы с пространственными и временными параметрами позволяет сделать вывод о формировании автором двух хронотопов «Борьба» и «Сопротивление», направленных на выражение личностных позиций автора и социально-исторического смысла, связанного с важностью происходивших событий и героизмом людей.

Прецедентные антропонимы религиозного происхождения (теонимы) очерчивают часть религиозной картины мира героев произведений В.П. Астафьева. В силу специфики теонимических знаков, которая проявляется в полионимии, базирующейся на тождественности объектов номинации, прецедентные онимы данной группы могут быть соотнесены с номинациями:

1) Бога - Христос, Господь Бог, Господь, Владько Всевыиний, Всевышний, Спаситель;

2) Пресвятой Девы Марии - Богородича, Пресвятая Богородииа, Святая Дева, Матушка, Владьчича Небесная, Заступнича Пресвятая, Мира Заступнича, Царича Небесная;

3) христианских святых - Магдалина, Илья-пророк.

Зафиксированный нами корпус теонимов представляет собой список имен собственных, источником которых послужил текст Библии. Имена божественных лиц используются автором для воплощения основных концептуальных религиозных смыслов христианской религии: «Спасения», «Божественной власти», «Заступничества», а также раскрывает религиозные убеждения самого автора.

Наименьшим количеством прецедентных имен (7\%) представлена область научного знания. Использованные В.П. Астафьевым онимы

5 Один из руководителей советского партизанского движения в Сибири. 
принадлежат лицам, представляющим такие сферы науки, как философия - Карл Маркс, Лассаль, Ницше, Фридрих Энгельс; теология Блаженный Августин; физика/химия - Менделеев; география - Иван Папанин6 ; педагогика - Макаренко, Уиинский, а также автором упоминаются две фамилии ученых-исследователей Сибири и Красноярского края, родины писателя, - Крашенников и Паллас. Фреквентативное преобладание прецедентных имен в сфере науки «Философия» подчеркивает всемирно-историческое значение трудов этих ученых, повлиявших на идеологическое самосознание народов многих стран мира и самого автора.

Анализ контекстного функционирования прецедентных имен в исследуемых произведениях В.П. Астафьева позволяет определить особенности индивидуально-авторский картины мира. Преобладание прецедентных онимов в функции прямой референции насыщает идейно-проблемное содержание и усиливает образность художественных произведений.

При этом нами выявлены следующие характерные особенности функционирования таких единиц. Используя прецедентное имя в ткани художественного произведения, автор

1) акцентирует внимание на его дифференциальных признаках:

а) внешности: Да я уж и левшу Крючкова и белоглазую Ладынину возненавидела [Астафьев 2009, 192];

б) проявлении характера в действиях, сопровождающихся при этом ярко выраженной оценочностью и аксеологичностью: 1. Большевики, те, что за войной, - тоже демагоги, как фюрер наш драгоиенный и его прихлебатель Геринг, - любят в рыцарей поиграть [Астафьев 2009, 705]. 2. Мехлис и адмирал с красивой фамилией Октябрьский - вьскочка и жулик - мальм испугом отделались [Астафьев 2009, 333];

в) особенностях деятельности: Но красноармееи Булдаков вел себя примерно, вопрось задавал только по текущей политике, интересуясь в основном деятельностью Даладье и Чемберлена да кто правит ньне в Африке - чернье иль все еще белье колонизаторь-капиталистьл [Астафьев 2009, 38].

2) апеллирует к прецедентному тексту:

а) с указанием названия этого текста: 1. В клубе особой работь не велось, не до нее било, но фильмь для офицеров и их семей демон-

6 Иван Дмитриевич Папанин, доктор географических наук, полярный исследователь. 
стрировались, жень офичеров и штабники собирались вечерами в хор, репетировали, и давно уже, под руководством капитана Дубельта «Женитьбу» Гоголя... [Астафьев 2009, 145]. 2. Оказалось, что сочинил «Фому» Клод Фаррер, офичер франчузского флота, и не только ее, а и множество романов с такими завлекательньми названиями, которые нашим лениво мозгами пошевеливающим писателям и не снились [Астафьев II 1989, 366];

б) путем концентрации прецедентных имен в рамках одной синтагматической единицы. Так, имена следующих трех сказочных героев Кощей Бессмертньй, Василиса Прекрасная и Иванушка, упомянутые в повести «Последний поклон», несмотря на прием контаминации, отсылают непосредственно к сюжету определенной сказки: Говорят, ecли найдешь иветок папоротника - невидимкой станешь, можешь забрать все богатства у богатьх и отдать их бедньм, выкрасть у Кощея Бессмертного Василису Прекрасную и вернуть ее Ивануш$\boldsymbol{\kappa} \boldsymbol{e}$ [Астафьев I 1989, 21].

3) отсылает к определенному временному периоду с одновременным фокусированием на историческом событии, которое может быть расценено как прецедентная ситуация. В этой функции выступают прецедентные имена Наполеон, император Павел, иарь Лексей, зафиксированные в романе Прокляты и убитыл. Перечисленные правители связываются в сознании общества и автора с прошлыми веками, а периоды их правления - масштабными и судьбоносными военными действиями во внешней политике. Такой инвариант восприятия этих имен позволяет писателю одновременно противопоставить эту «новую, другую войну», которая описывается в романе, тем войнам, которые уже пережил народ: 1. То, что годилось для прошлой войнь или даже для войньи c Наполеоном, следовало отменить, перестроить, упростить, да не упрощать же до полного абсурда, до убогости, нищетьи, до полной безнравственности, ведь бойиьл первой роть по одежде, да и по условиям жизни и по поведению мало чем отличаются от арестантов ньнешних времен [Астафьев 2009, 103]. 2. Ответа Щусь не находил, не понимал, что действует машина, давняя тупая машина, не учитьваюшая того, что времена императора Павла давно минули, что война ньнче совсем другая, ито страна находится в тяжелейшем состоянии, и не усугублять бь ее беды и страдания, собраться бил с умом, сосредоточиться, перерешить многое [Астафьев 2009, 103]. 3. «Неуж, как при иаре Лексее, ишио дальше в леса уходить придется?» - тарашил порченнье трахомой глаза старообрядец-отшельник [Астафьев 2008, 190]. 
4) вводит прецедентные высказывания. Наивысшие фреквентативные показатели частотности употребления в этой функции отмечаются у прецедентных онимов со сферами-источниками «Литература: литературные деятели, писатели, поэты» и «Наука: философы, теологи, ученые-исследователи Сибири»: 1. Печаль моя светла. Печаль моя полна тобою!.. А. С. Пушкин [Астафьев II 1989, 218]. 2. Запись, сделанная, видать, еще в отроческие годы, в общем-то, ни о каком еще снобизме не свидетельствовала: «Природа - более мачеха, нежели мать - бросила человека в жизнь с нагим телом, слабьл, ничтожньим, с душою, которую тревожат заботьл, страшит робость, увлекают страсти, но в которой между тем, хотя полузадушенная, всегда остается божественная искра рассудка и гения». - Блаж. Августин [Астафьев 2008, 363]. 3. «на правой стороне Енисея есть пе$\underline{\text { шера }}$, - писал Крашенинников, - Овсянская назьввается (та самая, куда забегали мьи, играя, и где Санька видел домовниху с домовьм) [Астафьев II 1989, 323].

Прецедентные имена сферы-источника «История» характеризуются актуализацией трансформированных прецедентных высказываний. При этом количество прецедентных имен данной группы ограничено: Сталин, Гитлер, Бенеш, Геббельс, Розенберг. Инвариантом восприятия указанных имен выступают главные политические фигуры времен Великой Отечественной войны, что позволяет автору не только ретранслировать исторический подтекст и определенные исторические события, но и создать максимальную образность описываемых действий. Так, например, в романе «Прокляты и убиты» при описании тяжелого положения солдат в военных лагерях и на передовой, их голодного и обморочного состояния, зачастую беспощадного издевательства со стороны командующих армиями, приводятся слова Гитлера, усиливающие эмоциональное воздействие описываемых событий: Гитлер еще до начала военньх действий в России утверждал, что война здесь будет вестись вовсе не по рьиарским правилам, это будет война идеологий и расовьх противоречий, вестись она будет с беспрецедентной, безжалостной жестокостью [Астафьев 2009, 360].

5) отсылает к результатам научной или творческой деятельности прецедентных личностей. Такой тип функционирования характерен в наибольшей степени для прецедентных имен со сферами-источниками «Наука» и «Искусство: музыка». Атрибутами таких онимов выступают элементы, тесно связанные с означаемым прецедентного имени, а именно: «труды», «мелодия», «симфония», «полонез», «вторая соната». 
Таким образом, количественная и частотная представленность прецедентных имен в художественном ономастиконе произведений В. П. Астафьева, установленные социокультурные сферы-источники прецедентности и особенности функционирования данных социокультурных значимых единиц позволяют определить главные культурные конституенты в авторском восприятии национальной концептосферы, выявить индивидуальные интенции в объективации и понимании окружающей действительности, а также способах ее отражения в художественном тексте.

\section{Литература}

Астафьев В.П., 1989, Последний поклон: повесть, Москва.

Астафьев В.П., 2008, Царь-рыба: повествование в рассказах, Москва.

Астафьев В.П., 2009, Прокляты и убиты: роман, Москва.

Нахимова Е.А., 2007, Прецедентные имена в массовой коммуникаиии, Екатеринбург.

\section{PRECEDENTIAL NAME IN THE AUTHOR'S WORLDVIEW BY V. ASTAFJEV}

S U M M A R Y

The article deals with the description of precedential names as a special subsystem of literary onomastic space which represents the personal worldview by V. Astafjev. The socio- and cultural spheres of the precedential phenomenon revealed in V. Astafjev's creative work are presented. The individual intention in objectification and understanding of the given reality is determined as well as the ways they can be reflected in a literary text. 